\title{
Does the Coraco-acromial Angle Contribute to the Diagnosis of Impingement Syndrome?
}

\section{Korako-akromial Açının İmpingement Sendromu Tanısına Katkısı Var Mı?}

\section{(D) Ersen Ertekin¹, (D) Zehra Seznur Kasar²}

${ }^{1}$ Aydın Adnan Menderes University Faculty of Medicine, Department of Radiology, Aydın, Turkey

${ }^{2}$ Aydın Adnan Menderes University Faculty of Medicine, Department of Anatomy, Aydın, Turkey

Abstract

Objective: The aim of the present study is to investigate the contribution of the coraco-acromial angle to the diagnosis of impingement syndrome.

Method: The magnetic resonance images of the shoulder of 159 patients (96 females, 63 males) with impingement syndrome and 201 control cases (113 females, 88 males) from 2017 to 2019 were retrospectively evaluated. On the sagittal plane T2-weighted images, the shortest distances of humeral head to the acromion and the coracoid process, and the angle between longitudinal axis of the coraco-acromial ligament and longitudinal axis of the acromion were measured. To evaluate intraobserver reliability, all measurements were repeated two weeks later.

Results: The mean values of coraco-humeral distance, acromio-humeral distance and coraco-acromial angle were $8.39 \pm 5.97 \mathrm{~mm}, 8.07 \pm 4.00 \mathrm{~mm}$ and $123.45 \pm 11.10^{\circ}$, respectively, in the patient group, and $10.32 \pm 2.52 \mathrm{~mm}$, $10.69 \pm 2.19 \mathrm{~mm}$ and $124.75 \pm 6.95^{\circ}$, respectively, in the control group. While there was a significant difference between the patient and control groups in terms of coraco-humeral and acromio-humeral distances $(p<0.05)$, there was no significant difference in terms of coraco-acromial angle ( $p>0.05$ ). Elsewise, no correlation was found between impingement syndrome and coraco-acromial angle, since there were moderately negative correlations in terms of coraco-humeral and acromio-humeral distances.

Conclusion: Unlike the coraco-humeral and acromio-humeral distances, there was no correlation between coraco-acromial angle and impingement syndrome.

Keywords: Coraco-acromial angle, impingement syndrome, magnetic resonance imaging

\section{Öz}

Amaç: Bu çalışmanın amacı korako-akromial açının sıkışma sendromu tanısına katkısını araştırmaktır.

Yöntem: 2017-2019 yılları arasında sıkışma sendromlu 159 hastanın (96 kadın, 63 erkek) ve 201 kontrol olgusunun (113 kadın, 88 erkek) omuz manyetik rezonans görüntüleri geriye dönük olarak değerlendirildi. Sagittal düzlem T2 ağırlıkı görüntülerde, humerus başı ile akromion ve korakoid proçesin en kısa mesafeleri ve korako-akromial ligamentin uzunlamasına ekseni ile akromionun uzunlamasına ekseni arasındaki açı (korako-akromial açı) ölçüldü. Gözlemci içi güvenilirliği değerlendirmek için, tüm ölçümler iki hafta sonra tekrarlandı.

Bulgular: Ortalama korako-humeral mesafe, akromio-humeral mesafe ve korako-akromial açı değerleri hasta grubunda sırasıyla 8,39 $\pm 5,97 \mathrm{~mm}$, $8,07 \pm 4,00 \mathrm{~mm}$ ve $123,45 \pm 11,10^{\circ}$ iken, kontrol grubunda $10,32 \pm 2,52 \mathrm{~mm}$, $10,69 \pm 2,19 \mathrm{~mm} 124,75 \pm 6,95^{\circ}$ idi. Hasta ve kontrol grubu arasında korakohumeral ve akromio-humeral mesafeler açısından anlamlı fark varken $(p<0,05)$, korako-akromial açı açısından anlamlı fark yoktu $(p>0,05)$. Korako-humeral ve akromio-humeral mesafeler ile sıkışma sendromu arasında orta derecede negatif korelasyonlar mevcut iken korakoakromial açı ile sıkışma sendromu arasında bir ilişki saptanmadı.

Sonuç: Korako-humeral ve akromio-humeral mesafelerden farklı olarak, korako-akromial açı ile sıkışma sendromu arasında bir ilişki saptanmadı.

Anahtar kelimeler: Korako-akromial açı, manyetik rezonans görüntüleme, sıkışma sendromu

Address for Correspondence: Ersen Ertekin, Aydın Adnan Menderes University Faculty of Medicine, Department of Radiology, Aydın, Turkey E-mail: drersen@hotmail.com ORCID: orcid.org/0000-0001-7282-0725 Received: 17.11.2020 Accepted: 11.12.2020

Cite this article as: Ertekin E, Kasar ZS. Does the Coraco-acromial Angle Contribute to the Diagnosis of Impingement Syndrome? Bagcilar Med Bull 2021;6(2):99-104

${ }^{\circ}$ Copyright 2021 by the Health Sciences University Turkey, Bagcilar Training and Research Hospital Bagcilar Medical Bulletin published by Galenos Publishing House. 


\section{Introduction}

Impingement syndrome is one of the most common causes of shoulder pain in the subacromial region. A leading cause of this syndrome is the compression of the supraspinatus tendon and long head of biceps brachi muscle between the humeral head and coraco-acromial ligament (1). Shoulder impingement syndrome was first described by Neer (2). He explained this syndrome as a mechanical compression of the rotator cuff tendons under the antero-inferior part of the acromion in the forward flexion and internal rotation position of the shoulder (3).

The superior border of the subacromial space is formed by one third anterior part of acromion, coraco-acromial ligament, coracoid process, acromio-clavicular joint and acromio-clavicular ligament. The lower border is formed by humeral head and tuberculum majus (4). In impingement syndrome, the rotator cuff tendons are compressed in subacromial space due to the pathologies of the anatomic structures that limit this space. Impingement of the tendons may occur due to internal and external causes (5). Among the external causes, the morphological structure of acromion and acromio-clavicular joint pathologies, which causes narrowing of the subacromial space, is the most common (6). Acromion variations are also considered among the causes of impingement and might lead to rotator cuff rupture (7). Internal causes of impingement are tendon degenerations due to decreased vascularity and recurrent loads in rotator cuff tendons (8). The rotator cuff tendons provide the dynamic stabilization of the shoulder joint along with the long head of biceps brachi, pectoralis major, latissimus dorsi and serratus anterior musles, while the joint capsule, glenoidal labrum, glenohumeral ligaments and negative joint pressure ensure the static stabilization. Although the diagnosis of impingement syndrome is made through clinical examination, imaging methods are helpful for an accurate diagnosis.

Magnetic resonance imaging (MRI) is widely used in musculoskeletal imaging due to its high soft tissue resolution. Shoulder MRI can help to evaluate the pathological condition causing compression, the condition of the tendon exposed to compression and possible additional findings $(6,7)$. The main parameters used for the diagnosis of impingement syndrome on MRI are the reduction of coraco-humeral distance (CHD) and acromiohumeral distance (AHD). However, the reduction of these distances is not always compatible with clinical findings. We think that the addition of new anatomical data may increase the clinico-radiologic compliance. Therefore, we investigated whether there was a correlation between the coraco-acromial angle (CAA) and impingement syndrome, in addition to AHD and CHD.

\section{Materials and Methods}

Approval was obtained from the University of Aydın Adnan Menderes Ethics Committee for non-interventional clinical trials within our institution (protocol no: 2019/175). Since it was designed retrospectively and only MRI images of the patients were evaluated, no "voluntary consent form" was obtained from the patients.

\section{Patient Selection}

From May 2017 to May 2019, shoulder MRIs of patients older than 18 years were scanned retrospectively. Among patients referred to our clinic for shoulder MRI with a prediagnosis of impingement syndrome, those whose MRI results were compatible with impingement syndrome were identified. Patients with history of trauma, rheumatologic disease or severe glenohumeral arthrosis, and tumors, those who had previous operations and those with poor MRI quality were excluded from the study. Consequently, 159 patients (96 females, 63 males) diagnosed with impingement syndrome were included in the study. Two hundred-one cases (113 females, 88 males) with a similar age distribution to the patient group without clinical prediagnosis of impingement syndrome and with normal shoulder MRI report were defined as the control group.

\section{MRI Evaluation}

All MRI examinations were obtained with a 1.5 Tesla MR device (Philips Achieva, Philips Medical Systems, Nederland BV) using an 8-channel superficial shoulder coil. As a standard shoulder MRI scan, T1 and T2-weighted series in the sagittal oblique plan, T2-weighted fat-suppressed series in the coronal oblique plan, and T2-weighted series in the axial plane were obtained. All measurements were made on T2-weighted sections in the sagittal oblique plane.

AHD and CHD measurements were made from the section where the distance between the humeral head-acromion and humeral head-coracoid process was the shortest, respectively. CAA was measured between the longitudinal axis of the coraco-acromial ligament and the line tangent to the inferior surface of the acromion (Figure 1). For intra-observer reliability analysis, all measurements were repeated after two weeks.

Acromion shapes of all cases were evaluated on sagittal plane T2-weighted MR images, based on the morphological 
classification of Bigliani et al (9). Accordingly, acromion types were divided into three groups: type $1=$ flat, type $2=$ anteriorly curved, type $3=$ hooked.

\section{Statistical Analysis}

SPSS 22.0 program was used for the statistical analysis. The normality analysis of the obtained data was evaluated with the Kolmogorov-Smirnov test. The Student's t-test was used for the analysis of normally distributed data, and the MannWhitney $\mathrm{U}$ test for non-normally distributed data, with a significance level of $\alpha=0.05$. For the correlation analysis, the Pearson and Spearman correlation tests was used for normally and non-normally distributed data, respectively.

\section{Results}

One hundred and fifty-nine patients (96 females, 63 males) and 201 (113 females, 88 males) controls were included in our study. The average age of the patient group was $55.1 \pm 12.4$ years in females and $52.4 \pm 14.3$ years in males. The mean age of the control group was $47.4 \pm 10.5$ years in females and $40.2 \pm 13.5$ years in males. The average age of the patient group was higher than that of the control group for both males and females $(\mathrm{p}<0.05)$.

The mean values of CHD, AHD and CAA were 8.39 \pm 5.97 $\mathrm{mm}, 8.07 \pm 4.00 \mathrm{~mm}$ and $123.45 \pm 11.10^{\circ}$, respectively, in patients with impingement syndrome, and $10.32 \pm 2.52$

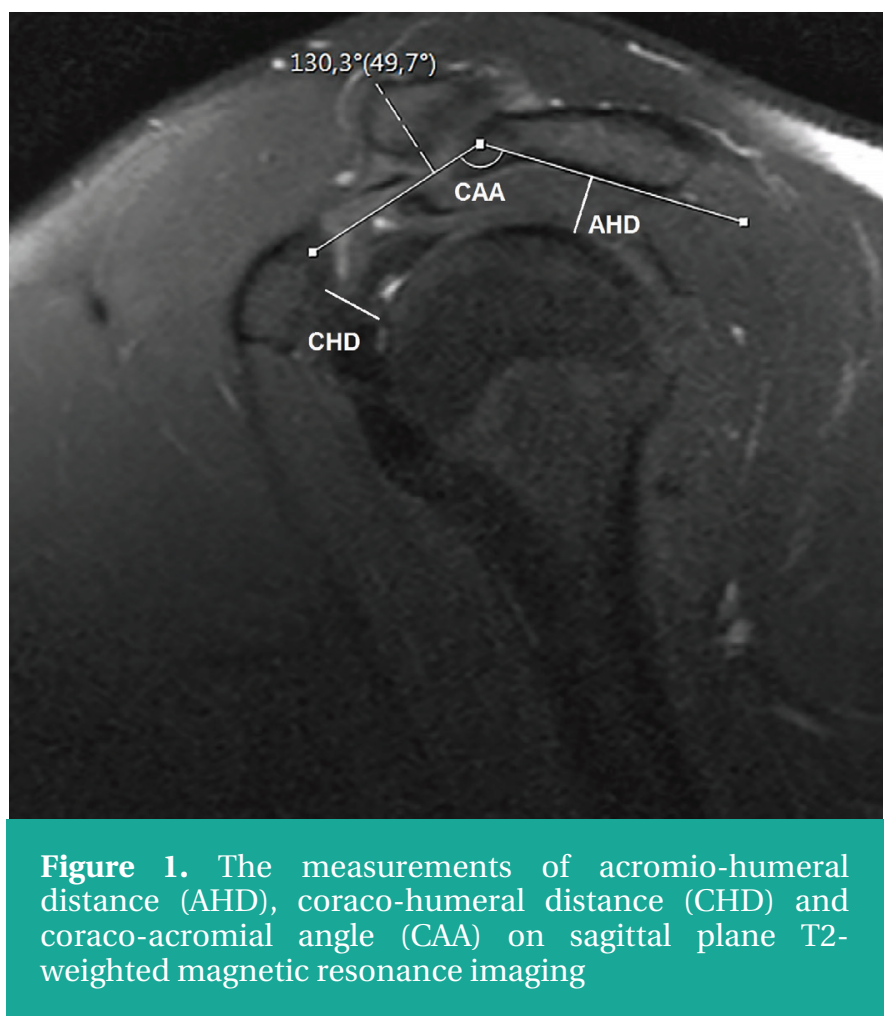

$\mathrm{mm}, 10.69 \pm 2.19 \mathrm{~mm}$ and $124.75 \pm 6.95^{\circ}$, respectively, in the control group. While there was a significant difference between the two groups in terms of CHD $(p=0.001)$ and AHD $(p=0.001)$, there was no significant difference in CAA $(\mathrm{p}=0.182)$. The statistical analyses of patients according to their gender, the distribution of age, CHD, AHD and CAA values by groups were summarized in Table 1, 2 .

In terms of acromion types of males, 37 were type I and 26 were type II in the patient group and 70 were type I and 18 were type II in the control group. While 54 of the female patients had type I and 42 had type II, 69 women had type I and 44 had type II acromion in the control group. We did not determine type III acromion in any group. In males, type II acromion was significantly higher in the patient group compared to the control group ( $\mathrm{p}=0.002$ ). We did not find a significant difference between the patient and control groups in women.

When the effect of gender was evaluated, there was a significant difference between men and women in the control group in terms of AHD ( $\mathrm{p}=0.04)$, CHD $(\mathrm{p}=0.00)$, CAA $(p=0.01)$ and acromion types $(p=0.01)$. There was no significant difference between the female and male patients in term of acromion type in the patient group ( $p>0.05$ ).

Correlation analysis indicated moderately negative correlation between impingement syndrome and CHD $(r=0.455)$ and AHD ( $r=0.590)$. There was also a moderate negative correlation between the age and CHD ( $r=0.320)$ and AHD ( $r=0.169)$. In addition, a moderately positive

\begin{tabular}{|c|c|c|c|}
\hline Female & $\begin{array}{l}\text { Patient } \\
\text { group }(n=96)\end{array}$ & $\begin{array}{l}\text { Control } \\
\text { group }(n=113)\end{array}$ & $\mathbf{p}$ \\
\hline Age & $55.1 \pm 12.4$ & $47.4 \pm 10.5$ & 0.001 \\
\hline $\begin{array}{l}\text { Acromio-humeral } \\
\text { distance }(\mathrm{mm})\end{array}$ & $8.0 \pm 4.9$ & $10.4 \pm 2.1$ & 0.001 \\
\hline $\begin{array}{l}\text { Coraco-humeral } \\
\text { distance }(\mathrm{mm})\end{array}$ & $8.1 \pm 7.4$ & $9.8 \pm 2.3$ & 0.031 \\
\hline Coraco-acromial angle $\left({ }^{\circ}\right)$ & $122.9 \pm 13.5$ & $123.6 \pm 6.9$ & 0.637 \\
\hline
\end{tabular}

Table 2. Measurement results of males in the patient and control groups

\begin{tabular}{llll} 
Male & $\begin{array}{l}\text { Patient group } \\
(\mathbf{n = 6 3 )}\end{array}$ & $\begin{array}{l}\text { Control } \\
\text { group }(\mathbf{n = 8 8})\end{array}$ & $\mathbf{p}$ \\
\hline Age & $52.4 \pm 14.3$ & $40.2 \pm 13.5$ & 0.001 \\
$\begin{array}{l}\text { Acromio-humeral } \\
\text { distance }(\mathbf{m m})\end{array}$ & $8.1 \pm 2.1$ & $11.0 \pm 2.3$ & 0.001 \\
$\begin{array}{l}\text { Coraco-humeral } \\
\text { distance }(\mathbf{m m})\end{array}$ & $8.7 \pm 2.5$ & $10.9 \pm 2.6$ & 0.001 \\
\begin{tabular}{l} 
Coraco-acromial angle $\left(^{\circ}\right)$ \\
\hline
\end{tabular} & $124.4 \pm 5.7$ & $126.2 \pm 6.8$ & 0.083 \\
\hline
\end{tabular}


correlation was found between impingement syndrome and age parameter $(\mathrm{r}=0.357)$.

In the intra-observer reliability analysis, there was a high correlation between both measurements in terms of CHD, AHD and CAA ( $\mathrm{r}=0.860,0.869$ and 0.922 , respectively) (Table 3).

\section{Discussion}

In the shoulder impingement syndrome, the subacromial space is contracted due to internal or external factors, and tendons are compressed in this interval during joint movements. Although the diagnosis of the syndrome is usually based on clinical findings, in most cases, radiological imaging methods are used for confirmation or to reveal the etiology. In order to diagnose impingement radiologically, the narrowing in AHD and CHD distances is considered. However, contraction of these distances is not always consistent with clinical symptoms and signs. Therefore, we thought that adding new anatomical data to existing radiological diagnostic criteria for the diagnosis of impingement might increase clinico-radiologic compliance.

In the current study, we investigated the contribution of the CAA to the diagnosis of impingement syndrome in addition to the distances between humeral head with coracoid process and acromion. According to our findings, AHD and CHD decreased significantly in impingement syndrome compared to the control group, in parallel to the literature $(10,11)$. In contrast, CAA decreased slightly in impingement syndrome, but no significant difference was observed between the patient and the control groups.

In our study, AHD and CHD were measured at the shortest distance on the sagittal plane MRI. However, there is no clear consensus on the method of measuring CHD and AHD in the literature. Some researchers made their measurements from MR images in the sagittal plane, some in the coronal plane, some in axial or combined (10-14). In spite of this, in most of these studies, measurements were made at the level where these distances were the shortest. Unlike measuring in different planes, some researchers made measurements from different locations to evaluate

Table 3. Intra-observer reliability measurement results

\begin{tabular}{lll} 
& $\mathbf{r}$ & $\mathbf{p}$ \\
\hline Acromio-humeral distance & 0.922 & 0.001 \\
Coraco-humeral distance & 0.869 & 0.001 \\
Coraco-acromial angle & 0.860 & 0.001 \\
\hline
\end{tabular}

the effect of the measurement site on diagnosis $(12,14)$. Park et al. (12) measured AHD on three different points, as medial, lateral and central of the acromion, on the sagittal plane MRI of 56 male and 24 female patients with impingement. They stated that AHD measurements taken from the lateral and center of the acromion decreased in correlation with the impingement syndrome and that AHD measurements made from the medial of the acromion did not show a significant difference between the groups.

Despite the high correlation between impingement syndrome and CHD-AHD, the unsatisfactory clinicoradiologic correlation leads researchers to different searches $(15,16)$. We performed CAA measurements that we thought might be useful for diagnosis for this purpose, but we did not find a significant difference between the patient and control groups in terms of CAA measurements. Similar to our study, Cay et al. (15) measured AHD, CHD and CAA of 40 patients who underwent shoulder arthroscopy due to rotator cuff rupture and 28 healthy cases on the sagittal plane MRI. They stated that AHD, CHD and CAA were significantly decreased in patients compared to the control group. McGinley et al. (16) retrospectively evaluated the MRI of 89 impingement cases. In their study, they measured acromion angles on MRI in the coronal plane and divided the patients into two groups as those with an acromion angle higher and lower than $7.5^{\circ}$. They also compared the two groups by measuring the distance between coracoacromial ligament and humeral head. As a result, they found that this distance was significantly shorter in the group with low acromion angle.

In our study, we also examined the relationship between acromion types and impingement syndrome. In male cases, a significant difference was observed between the patient and control groups in terms of acromion types, while we could not find any significant difference in women. We think that the reason for this was the absence of type III acromion in our study. This condition may also have contributed to the fact that females' AHD and CHDs are less than those of males. There are studies in the literature comparing acromion type with CHD or AHD in patients with impingement syndrome. Duymuş et al. (17) compared acromion types and AHD in 38 male and 62 female patients with impingement syndrome retrospectively. In their study, they classified the acromion into 4 groups according to their morphology (type I: flat, type II: parallel to the caput humerale; type III: hook-shaped; type IV: convex bottom surface). As a result, they found that there was no significant difference between acromion types and AHD 
measurements in men, whereas AHD was shorter in type III acromion than in other types in female patients. Asal and Şahan (11) divided the coracoid process of 200 patients (87 males and 113 females) with subcoracoid impingement syndrome into three groups: type I flat, type II osteophytic and type III hooked. In their measurements on the MRI in the axial plane, they found that the CHD in the type III group was significantly shorter than in the type I group.

In accordance with the literature, we found that the mean age of both male and female patients was higher than that of the control group, due to aging-related ligamentous laxity and structures degenerative changes (decreased vascularity, etc.) in the subacromial space $(12,17)$.

Our study showed that women in the control group had lower AHD, CHD and CAA values than men in the control group. But there was no significant difference between male and female patient groups in terms of AHD, CHD and CAA values. This condition may be attributed to the anatomical structure difference between men and women. Unlike our study, Duymuş et al. (17) examined 100 patients with impingement syndromes (38 men, 62 women) and found AHD to be shorter in women than in men.

\section{Study Limitations}

Our study has some limitations. The most important limitation was the lack of clinical examination data due to the retrospective nature of the study. Making the measurements by a single researcher can be considered as a limitation. However, the measurements of all cases were repeated after two weeks and a high correlation was found in the intra-observer reliability analyses. Another limitation may be the lack of etiological classification in the patient group, which may reveal different anatomical signs.

\section{Conclusion}

As a result, the findings in our study revealed a significant decrease in the CHD and AHDs in impingement syndrome, while there was no significant difference in the CAA values. However, studies with extended study groups and different measurement techniques are needed for a better understanding of impingement syndrome and etiological causes.

\section{Ethics}

Ethics Committee Approval: Approval was obtained from the University of Aydın Adnan Menderes Ethics Committee for non-interventional clinical trials within our institution (protocol no: 2019/175).
Informed Consent: Since it was designed retrospectively and only MRI images of the patients were evaluated, no "voluntary consent form" was obtained from the patients.

Peer-review: Externally peer-reviewed.

\section{Authorship Contributions}

Concept: E.E., Z.S.K., Design: E.E., Z.S.K., Data Collection or Processing: E.E., Z.S.K., Analysis or Interpretation: E.E., Z.S.K., Literature Search: E.E., Z.S.K., Writing: E.E., Z.S.K.

Conflict of Interest: No conflict of interest was declared by the authors.

Financial Disclosure: The author declared that this study has received no financial support.

\section{References}

1. Akgun K. Shoulder pain. In Desease of motion system, Tuzun F, Eryavuz M, Akairmak U (editors). Istanbul: Nobel Medical Bookstore, 1997:193-210.

2. Neer CS 2nd. Anterior acromioplasty for the chronic impingement syndrome in the shoulder: a preliminary report. J Bone Joint Surg Am 1972;54(1):41-50.

3. Neer CS 2nd. Impingement lesions. Clin Orthop Relat Res 1983;(173):70-77.

4. Özsoy MH, Fakığlu O, Aydoğan NH. Subacromial impingement syndrome. TOTBİD J 2013;12(4):340-352.

5. Poppen NK, Walker PS. Forces at the glenohumeral joint in abduction. Clin Orthop Relat Res 1978;(135):165-170.

6. Akman S, Küçükkaya M. Subacromial impingement syndrome: pathogenesis, clinical features, and examination methods. Acta Orthop Traumatol Turc 2003;37(Suppl 1):27-34.

7. Ekin A, Tatari H, Kabaklığlu T. Omuz impingiment sendromu: Anatomi, etiyoloji, sinıflama ve tedavi. Turkish J Arthroplasty Arthroscopic Surg 1994;5(8):19-25.

8. Finnan RP, Crosby LA. Partial-thickness rotator cuff tears. J Shoulder Elbow Surg 2010;19(4):609-616.

9. Bigliani LU, Morrison DS, April EW. The morphology of the acromion and its relationship to rotator cuff tears. Orthop Trans 1986;10:228.

10. de Oliveira França F, Godinho AC, Ribeiro EJ, Falster L, Búrigo LE, Nunes RB. Evaluation of the acromiohumeral distance by means of magnetic resonance imaging umerus. Rev Bras Ortop 2016;51(2):169-174.

11. Asal N, Şahan MH. Radiological Variabilities in Subcoracoid Impingement: Coracoid Morphology, Coracohumeral Distance, Coracoglenoid Angle, and Coracohumeral Angle. Med Sci Monit 2018;24:8678-8684.

12. Park HJ, Lee SY, Choi YJ, Park JH, Kim E. Association between subacromial impingement and acromiohumeral distance on MRI. Iran J Radiol 2018;15(2):e13811.

13. Cay N, Tosun O, Doğan M, Karaoğlanoğlu M, Bozkurt M. The effect of morphometric relationship between the glenoid fossa and the 
humeral head on rotator cuff pathology. Acta Orthop Traumatol Turc 2012;46(5):325-331.

14. Giaroli EL, Major NM, Lemley DE, Lee J. Coracohumeral interval imaging in subcoracoid impingement syndrome on MRI. AJR Am J Roentgenol 2006;186(1):242-246.

15. Cay N, Tosun O, Işık C, Unal O, Kartal MG. Bozkurt M. Is coracoacromial arch angle a predisposing factor for rotator cuff tears? Diagn Interv Radiol 2014;20(6):498-502.
16. Mc Ginley JC, Agrawal S, Biswal S. Rotator cuff tears: association with acromion angulation on MRI. Clin Imaging 2012;36(6):791796.

17. Duymuş M, Asal N, Bozkurt A, Güneş Orman G, Yeşilkaya Y, Yılmaz Ö. Acromion Types and Subacromial Distances in Symptomatic Patients; MRI Findings. Kafkas J Med Sci 2012;2(2):60-65. 